\title{
A functionally active RAR $\alpha$ nuclear receptor is expressed in retinoic acid non responsive early myeloblastic cell lines
}

\author{
A Grande ${ }^{1}$, M Montanari ${ }^{1}, \mathrm{R}$ Manfredini ${ }^{1}$, E Tagliafico', \\ T Zanocco-Marani ${ }^{1}$, F Trevisan ${ }^{1}$, G Ligabue ${ }^{1}$, M Siena $^{1}$, \\ St Ferrari ${ }^{1}$ and Se Ferrari ${ }^{\star, 1}$ \\ ${ }^{1}$ Dipartimento di Scienze Biomediche, Sezione di Chimica Biologica, Università \\ di Modena e Reggio Emilia, Modena, Italy \\ * Corresponding author: S Ferrari, Dipartimento di Scienze Biomediche, Sezione \\ di Chimica Biologica, Università di Modena e Reggio Emilia, Via Campi 287, \\ 41100, Modena, Italy; Tel: ++39/059/2055400; Fax: ++39/059/2055410, \\ E-mail: sergio@unimo.it
}

Received 3.2.00; revised 24.7.00; accepted 25.8.00

Edited by A Jetten

\begin{abstract}
Although all-trans retinoic acid (ATRA) can restore the differentiation capacity of leukemic promyelocytes, early leukemic myeloblasts are conversely not responsive to ATRA induced granulocytic differentiation. To assess whether this resistance to ATRA is related to an impaired function of the Retinoic Acid Receptor $\alpha$ (RAR $\alpha$ ), we performed an analysis of $\mathrm{RAR} \alpha$ expression and transactivation activity, in several myeloid leukemic cell lines, representative of different types of spontaneous acute myeloid leukemias. Our results indicate that a functionally active RAR $\alpha$ nuclear receptor is expressed in all the analyzed cell lines, regardless of their differentiation capacity following exposure to ATRA. The observation that ATRA treatment is able to induce the expression of retinoic acid target genes, in late- but not in early-myeloblastic leukemic cells, raises the possibility that the differentiation block of these cells is achieved through a chromatin mediated mechanism. Acetylation is apparently not involved in this process, since the histone deacetylase inhibitor trichostatin $A$, is not able to restore the differentiation capacity of early leukemic myeloblasts. Further investigation is needed to clarify whether myeloid transcription factors, distinct to RAR $\alpha$, play a role in the resistance of these cells to ATRA treatment. Cell Death and Differentiation (2001) 8, 70-82.
\end{abstract}

Keywords: RAR $\alpha$;ATRA; myeloid differentiation; early myeloblasts

Abbreviations: Ab, antibody; AML, acute myeloid leukemia; AP, alkaline phosphatase; APL, acute promyelocytic leukemia; ATRA, all-trans retinoic acid; $\beta$-gal, $\beta$-galactosidase; CAT, chloramphenicol acetyltransferase; DP, direct primer; EMSA, electrophoretic mobility shift assay; HDAC, hystone deacetylase; IRF-1, interferon regulatory factor-1; MGG, May Grünwald Giemsa; NE, nuclear extract; RA, retinoic acid; RAR $\alpha$, retinoic acid receptor $\alpha$; RARE, retinoic acid response element; $\mathrm{RP}$, reverse primer; rt, room temperature; $\mathrm{RT}-\mathrm{PCR}$, reverse transcription-polymerase chain reaction; $R X R$, retinoid x receptor; TGase, type II transglutaminase;
TSA, trichostatin A; VD, $1 \alpha, 25$ dihydroxyvitamin D3; VDR, vitamin D receptor

\section{Introduction}

Acute myeloid leukemias (AMLs) are heterogeneous neoplastic disorders arising from pluripotent hematopoietic stem cells, ${ }^{1}$ that lead to accumulation of immature myeloid cells (leukemic blasts) in bone marrow, peripheral blood and other organs. The growth advantage of AML blasts is not simply realized through an increased proliferation activity, but mainly through a prolonged survival time, due to a maturation arrest, and, consequently, to an unefficient activation of the apoptotic program. $^{2}$ Several cytogenetic abnormalities have been described in different forms of $\mathrm{AML}^{3}$ generally resulting in the disruption of transcription factors that are involved in the regulation of normal myelopoiesis. ${ }^{4}$ These cytogenetic abnormalities are supposed to contribute to the differentiation arrest of AML blasts, and the observation that distinct chromosomal aberrations may lead to the same leukemic phenotype, ${ }^{5}$ suggests the existence of final common pathways for the transcriptional control of myeloid differentiation. ${ }^{4}$ The French-American-British (FAB) classification ${ }^{6}$ of AMLs, based on morphological, cytochemical and immunophenotypic ${ }^{7}$ criteria, has clearly shown that maturation arrest of AML blast occurs at different stages of myeloid differentiation. Regardless of the stage of differentiation block, the possibility to induce AML cell maturation provides an opportunity to improve the clinical course of these malignancies. In spite of the physiological role exerted by colony stimulating factors (CSFs) in the regulation of normal myelopoiesis, these growth factors, besides being unable to induce the differentiation of AML cells, are also capable of stimulating the proliferative activity of such cells. ${ }^{8}$ The use of CSFs in the differentiation therapy of AMLs is therefore controversial. $^{8,9}$ Several chemical inducers, as all trans retinoic acid (ATRA) and $1 \alpha, 25$ dihydroxyvitamin D3 (VD), are, on the other hand, able to overcome the maturation arrest of AML cells, leading to the induction of granulocytic and mono-macrophagic differentiation respectively. ${ }^{10}$ These observations raise the question of the physiological role exerted by ATRA and VD in the regulation of normal hematopoiesis. In particular, ATRA delays the differentiation of primitive hematopoietic stem cells and, at the same time, enhances the terminal maturation of granulo-monocyte committed progenitors. ${ }^{11}$ Besides these physiological effects ATRA is also a powerful differentiating agent for specific types of AML blast cells. In vitro studies have in fact shown that ATRA induces granulocytic differentiation of human late myeloblast cell lines, such as HL-60, ${ }^{12}$ by interacting with RAR $\alpha / R X R$ heterodimers. ${ }^{13}$ The key role of $\mathrm{RAR} \alpha / \mathrm{RXR}$ heterodimers in the control of myeloid differentiation is also supported by the observation that a dominant negative, or an overexpressed 
'wild-type' RAR $\alpha$ receptor blocks neutrophil differentiation of primary myeloid cells at the promyelocyte stage, and this differentiation block can be overcome by treatment with ATRA. ${ }^{14-16}$ Furthermore ATRA can induce granulocytic differentiation, in vitro and in vivo, of acute promyelocytic leukemia (APL, or M3-AML) cells carrying the $t(15 ; 17)$ translocation. ${ }^{17,18}$ This genetic abnormality specifically occurs in the majority of APLs and generates the PML/RAR $\alpha$ fusion gene. ${ }^{19-21}$ In a limited number of APL cases alternative chromosomal translocations have been described, like the $t(11 ; 17)$ which generates a distinct fusion gene named PLZF-RAR $\alpha$, and the $t(5 ; 17)$ that gives rise to the NPM-RAR $\alpha$ fusion gene. ${ }^{5}$ The aberrant recruitment of nuclear co-repressor complexes, containing $\mathrm{N}-\mathrm{CoR}$ and histone deacetylase (HDAC), on promoter regions of RA target genes, has been claimed as a mechanism to explain the differentiation block of APL cells carrying PML/RAR $\alpha$ or PLZF$\mathrm{RAR} \alpha$ fusion genes ${ }^{22,23}$. More recently the aberrant recruitment of $\mathrm{N}-\mathrm{CoR} / \mathrm{HDAC}$ complexes on chromatin has also been proposed to be involved in the maturation arrest of M2 type AML cells carrying the $t(8 ; 21)$ translocation. ${ }^{24}$ These observations open the possibility for a therapeutic use of HDAC inhibitors, like trichostatin A (TSA) and sodium butyrate, as differentiating agents for AML blasts. ${ }^{25} \mathrm{AML}$ types distinct to M3-AML (M0, M1, M2, M4 and M5) are not responsive to ATRA induced granulocytic differentiation. ${ }^{26}$ Several myeloid cell lines have been established, starting from primary $A M L$ blasts, that maintain the peculiar differentiation block of the parental leukemic cells they derive from, and can therefore be considered interesting in vitro models to characterize the maturation arrest of AML cells. ${ }^{27}$ To identify the molecular mechanisms underlying the resistance to ATRA induced differentiation, we investigated $\operatorname{RAR} \alpha$ nuclear receptor expression, phosphorylation, DNA binding capacity, transactivation activity and ability to induce a ligand dependent expression of RA target genes, in eight leukemic myeloid cell lines, representative of the maturation block occurring in different types of spontaneous AMLs. Our data indicate that only late myeloblastic/promelocytic leukemic blasts are responsive to ATRA induced granulocytic differentiation, underlining that specific maturation windows exist, permissive to the activity of physiological differentiation inducers. In spite of this, functional RAR $\alpha / R X R$ heterodimers were detected in both ATRA responsive and non responsive myeloid leukemic populations.

\section{Results}

\section{ATRA induced differentiation of myeloid cell lines arrested at different levels of maturation}

Granulocytic differentiation was evaluated after 5 days of treatment with $10^{-6} \mathrm{M}$ ATRA, monitoring CD11b and CD14 antigen expression and cell morphology. ${ }^{27}$ As shown in Figure 1, immature myeloblastic cell lines such as K562 (myelo-erythroblastic), KG1a (M0 type), KG1 (M1 type) and the more differentiated cell lines THP1 and U937 (M5 type), are substantially not responsive to ATRA induced granulocytic differentiation since no induction of CD11b surface antigen occurs after ATRA treatment. Conversely the myeloblastic cell lines HL60 (M2/M3 type) and NB4 (M3 type) are responsive to ATRA induced granulocytic differentiation, since a clear induction of CD11b is observed in these cells (Figure 1), which is not coupled to expression of CD14 (not shown). Morphological evaluation shows that only HL60 and NB4 cell lines assume a granulocytic morphology after 5 days of ATRA treatment (data not shown). Exposure of AML1 cells to ATRA resulted in a massive cell death which was quite evident after $48 \mathrm{~h}$ of treatment, as assessed by morphology, cytofluorimetric evaluation of the hypodiploid DNA content and gel electrophoresis, that showed the typical DNA fragmentation ladder pattern (data not shown). ATRA induced apoptosis of AML1 cells can probably be considered a partial response to ATRA, as already described for other myeloid cell lines. ${ }^{28}$

\section{RAR $\alpha$ protein expression}

Western blot analysis, performed on NE before any treatment with ATRA, substantiates the presence of $R A R \alpha$ protein bands in all the analyzed myeloid cell lines (Figure 2), implying that $R A R \alpha$ is always expressed, regardless of the responsiveness to ATRA induced differentiation. Several RAR $\alpha$ immuno-reactive protein bands are detected in the analyzed NE, having a molecular weight (MW) of 54, 57 and $58 \mathrm{kDa}$. A similar pattern of RAR $\alpha$ protein expression has already been described in non hematopoietic cells. ${ }^{29}$ In NB4 cells the $110 \mathrm{kDa}$ PML-RAR $\alpha$ fusion protein is also detectable, as expected (Figure 2, lane 6). Interestingly, the higher size, 57-58 $\mathrm{kDa} \mathrm{RAR} \alpha$ doublet, is expressed in all the analyzed cell lines (Figure 2, lanes $1-8$ ), while the lower size, $54 \mathrm{kDa}, \operatorname{RAR} \alpha$ band, with the only exception of NB4 cells (Figure 2, lane 6), results to be expressed only in the more mature myeloid cell lines (Figure 2, lanes 4, 5, 7 and 8).

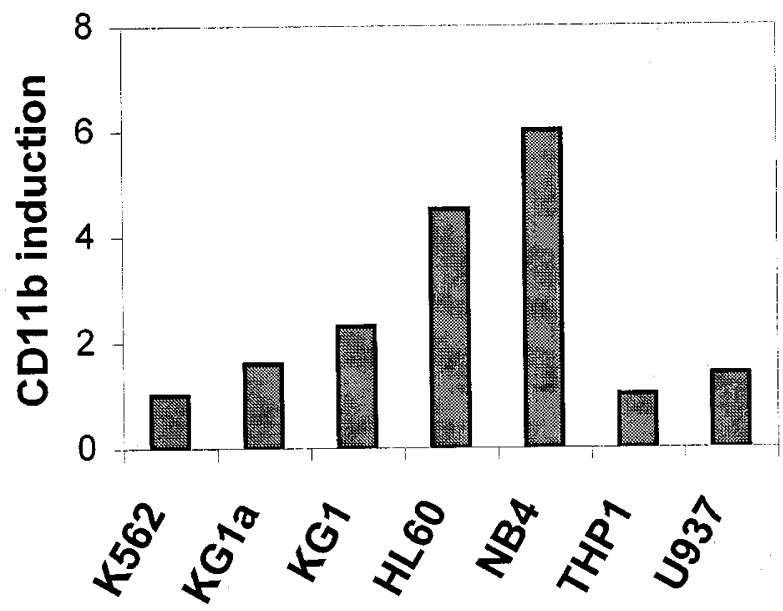

Figure 1 Cytofluorimetric analysis of CD11b expression in myeloid leukemic cell lines after treatment with $10^{-6} \mathrm{M}$ ATRA for 5 days. Expression levels of the analyzed surface antigen, represented in arbitrary units, are reported as fold induction of mean fluorescence upon stimulation with ATRA. Cell lines are reported at the bottom of the histogram. The reported data are representative of three distinct experiments performed, in which the variability of obtained results was lower than $15 \%$ 


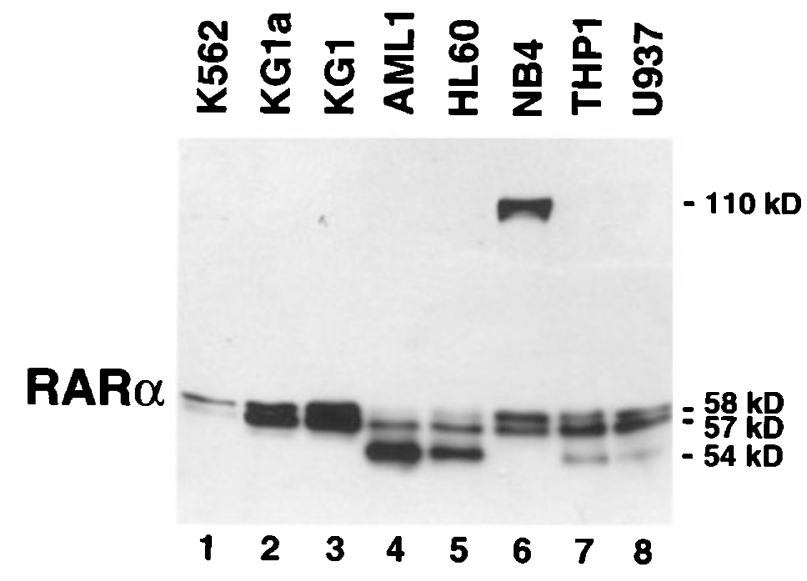

Figure 2 Western blot analysis of RAR $\alpha$ protein expression in nuclear extracts of the studied cell lines (lanes 1-8). The analyzed myeloid cell populations are reported at the top of the figure. RAR $\alpha$ and PML-RAR $\alpha$ protein sizes are reported on the right side
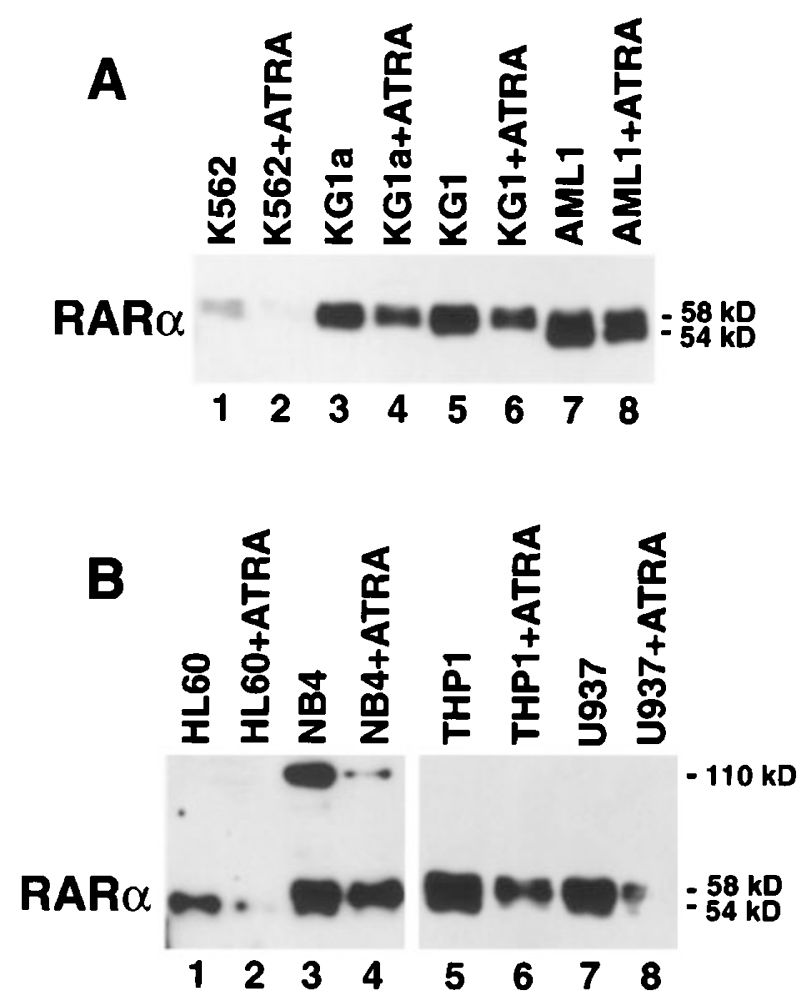

Figure 3 Western blot analysis of $\mathrm{RAR} \alpha$ protein expression in nuclear extracts of the examined cell lines before and after $12 \mathrm{~h}$ treatment with $10^{-6} \mathrm{M}$ ATRA. The analyzed myeloid cell populations are reported at the top of each panel. RAR $\alpha$ and PML-RAR $\alpha$ protein sizes are reported on the right side of each panel

A $12 \mathrm{~h}$ ATRA treatment induces a remarkable downregulation of RAR $\alpha$ and $P M L-R A R \alpha$ protein expression in all the analyzed cell lines (Figure $3 A, B$ ), according to the recent demonstration that ATRA triggers a rapid degradation of these proteins. ${ }^{30}$
Our data indicate that, although at different levels, RAR $\alpha$ protein is expressed in all the studied cell lines, showing that the expression of this nuclear receptor does not account for the different maturation capacity of the examined cell lines upon treatment with ATRA.

\section{RAR $\alpha$ protein phosphorylation}

As already reported, different size RAR $\alpha$ bands have been detected in the analyzed myeloid cell lines. To assess whether this complex pattern of RAR $\alpha$ protein expression was depending on differential phosphorylation, a distinct Western blot analysis was performed using AP treated NE. In all the examined NE, digestion of the higher size 57-58 kDa doublet with AP gives rise to a $54 \mathrm{kDa} R A R \alpha$ band (Figure $4 A-C$, lanes 2 and 5), while treatment of the lower size $54 \mathrm{kDa} R A R \alpha$ band with AP generates a $52 \mathrm{kDa} R A R \alpha$ form (Figure 4B, lane 2, C, lanes 2 and 5). The conversion to the de-phosphorylated 54 and $52 \mathrm{kDa} \operatorname{RAR} \alpha$ forms, is not observed when the analyzed NE are incubated in the same experimental conditions but in absence of the AP enzyme, excluding the possibility of a nonspecific degradation of the detected RAR $\alpha$ protein bands (Figure $4 A-C$, lanes 3 and 6 ). The 57-58 and 54 kDa RAR $\alpha$ forms still maintain different sizes following dephosphorylation with AP, that are 54 and $52 \mathrm{kDa}$ respectively. RT-PCR experiments, performed to specifically detect RAR $\alpha 1$ and RAR $\alpha 2$ isoforms, ${ }^{31}$ showed that they are simultaneously expressed in all the examined cell lines (data not shown), suggesting that these isoforms are not responsible for the expression pattern of the two dephosphorylated 54 and $52 \mathrm{kDa}$ RAR $\alpha$ proteins.

These results clearly demonstrate that, although at different levels, RAR $\alpha$ is phosphorylated in all the analyzed cell contexts.

\section{RAR $\alpha$ DNA binding capacity}

To assess whether response to ATRA treatment of the analyzed myeloid cell lines resides in a differential DNA binding capacity of RAR $\alpha / R X R$ heterodimers, we performed EMSA experiments in which NE were challenged with a RARE- $\beta 2$ oligonucleotide. In all the EMSA experiments, specificity of the shifted bands was confirmed by formation of a supershift complex, or by inhibition of the basal complex, following addition of an anti-RAR $\alpha$ monoclonal $A b$. An antiRXR monoclonal $A b$ was, in turn, able to substantiate a supershifted band when RXR was complexed with RAR $\alpha$ in a heterodimeric conformation. The addition of an isotype control $\mathrm{Ab}$ to some of the tested NE did not modify the band shift profile, as expected (Figure 5A, lanes 4 and 8), showing that the changes of EMSA pattern produced by the anti-RAR $\alpha$ and anti-RXR Ab were specific. In several control experiments specificity of the shift complexes was also confirmed by adding 100-fold excess of cold RARE- $\beta 2$ oligonucleotides (data not shown). As shown in Figure 5B, a basal complex is observed in ATRA non responsive K562 cells (lane 2), which is only weakly inhibited by the anti-RAR $\alpha$ $A b$ (lane 3) and partially supershifted by the anti RXR Ab (lane 4). In all the other analyzed cell lines, regardless of their responsiveness to ATRA treatment, a basal shift 


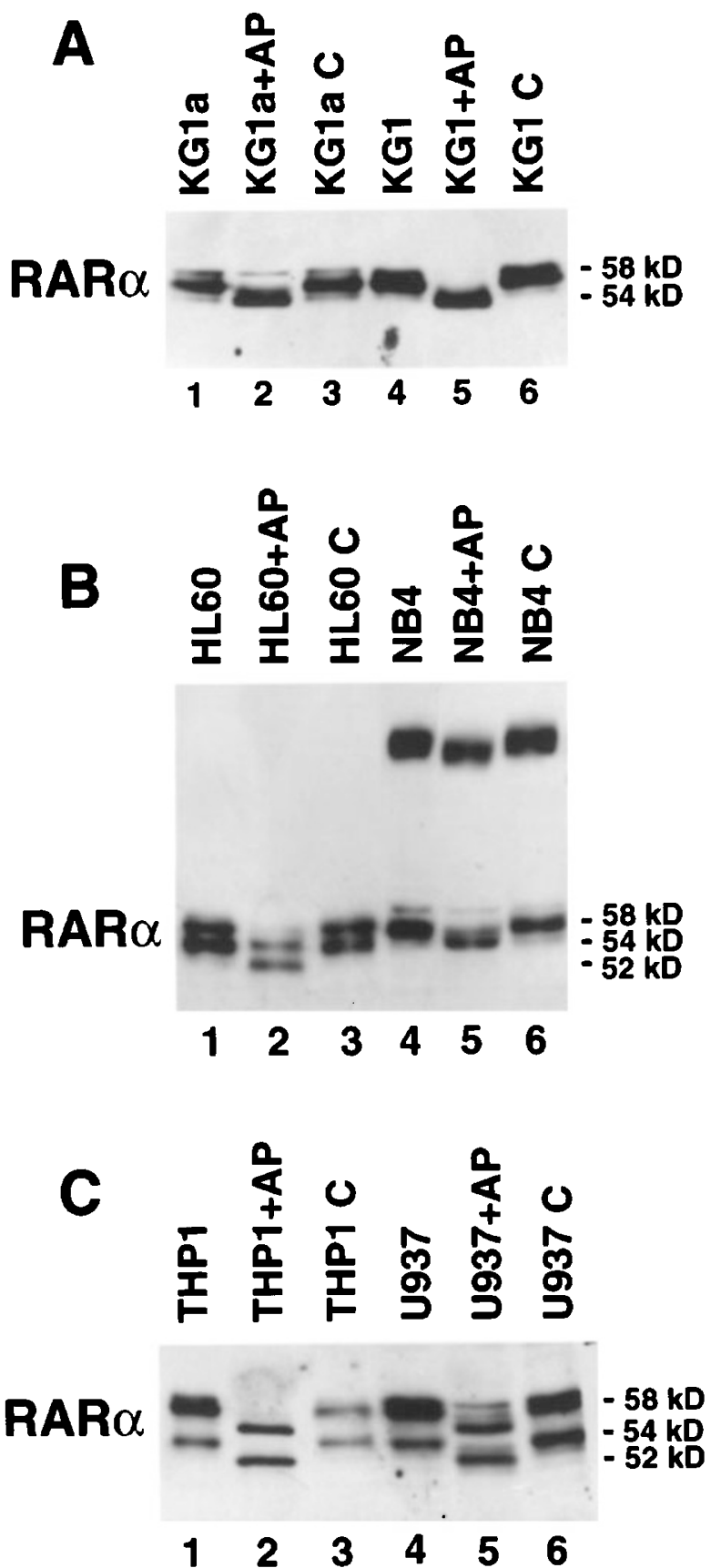

Figure 4 Western blot analysis of $\mathrm{RAR} \alpha$ protein expression in AP digested nuclear extracts of KG1a, KG1 (A), HL60, NB4 (B), THP1, U937 (C) cells. The analyzed myeloid cell populations are reported at the top of each panel. RAR protein sizes are reported on the right side of each panel. For each cell line the following samples have been analyzed: untreated NE (lanes 1 and 4 of each panel); AP treated NE (lanes 2 and 5 of each panel); control NE (C), treated as reported in Materials and Methods (lanes 3 and 6)

complex is detected (Figure 5B, lanes 5, 8, 11, 14, 17, 20 and 23), which is supershifted by addition of the anti-RAR $\alpha$ $\mathrm{Ab}$ (Figure 5B, lanes 6, 9, 12, 21 and 24) in most samples, and inhibited by addition of the same $A b$ in the remaining samples, that are, singularly, the ATRA responsive HL60 and NB4 cell lines (Figure 5B, lanes 15 and 18). In NB4 cell NE, an extra shift complex is also observed (Figure 5B, lane 17) which is apparently inhibited by the anti-RAR $\alpha$ Ab (Figure $5 B$, lane 18) and probably involves the chimeric PML-RAR $\alpha$ protein. Addition of the anti-RXR Ab always results in a clear supershift of the basal complex (Figure 5B, lanes 7, 10, 13, $16,19,22$ and 25). These data clearly show that, when NE of the analyzed cell lines are challenged with a RARE- $\beta 2$ oligomer, a shift complex containing RAR $\alpha / R X R$ heterodimers is formed. An exception is perhaps represented by $\mathrm{K} 562$ cells, where the basal shift complex is only to a minor extent depending on RAR $\alpha /$ RXR heterodimers, consistently with the low abundance of $\operatorname{RAR} \alpha$ protein, substantiated in these cells by Western blot analysis.

However, it is possible to conclude that ATRA induced maturation capacity of the analyzed myeloid cell lines cannot be ascribed to a differential DNA binding capacity of $\mathrm{RAR} \alpha / \mathrm{RXR}$ heterodimers, since all the examined NE are able to form RAR $\alpha / R X R$ dependent gel shift complexes.

\section{Transactivation activity of RAR $\alpha / R X R$ heterodimers on an exogenous RARE- $\beta 2$ dependent expression vector}

To evaluate the transactivation capacity of RAR $\alpha / R X R$ heterodimers in the different cell contexts, we performed transient transfection assays with a plasmid construct in which the reporter gene was expressed under the control of a RARE- $\beta 2$ element. As shown in Figure 6, ligand dependent transcriptional activation of the reporter gene occurs in all transfected cell lines, independently on their ability to differentiate after ATRA treatment. The extent of ATRA induced transcriptional activation varies from a 4-5-fold induction in K562, KG1a and KG1 cells, to a 8-14-fold induction in HL60, NB4, THP1 and U937 (Figure 7). Again, it is possible to conclude that the transactivation activity of RAR $\alpha$ / RXR heterodimers does not correlate with the capacity of the analyzed cell lines to undergo granulocytic differentiation following ATRA treatment.

\section{Transactivation activity of RAR $\alpha / R X R$ heterodimers on endogenous RA target genes}

Our results so far indicate that RAR $\alpha / \mathrm{RXR}$ heterodimers are able to bind a RARE- $\beta 2$ element, and to transactivate an exogenous RARE- $\beta 2$ carrying expression vector, in RA unresponsive myeloid cell lines. To assess if $R A R \alpha / R X R$ heterodimers are also able to transactivate endogenous RA target genes in ATRA unresponsive cell contexts, we performed a Northern blot analysis after a short treatment with ATRA. Among the RA target genes, we assessed the expression of IRF-1 and E3 genes, which have been shown to be associated with granulocytic differentiation. ${ }^{32,33}$ Results shown in Figure 8, upper panel, indicate that IRF1 mRNA is induced by ATRA treatment in AML1, HL-60 (M2/M3 types of AML), NB4 (M3 type of AML), THP1 and U937 cells (M5 types of AML) (Figure 8, upper panel, lanes 9-22), but not in myeloerythroid precursors (K562) and M0/M1 early myeloblastic cells (KG1a and KG1), i.e. in the more undifferentiated ATRA unresponsive cell lines (Figure 8, upper panel, lanes 1-8). A clear induction of E3 mRNA upon treatment with ATRA is only 

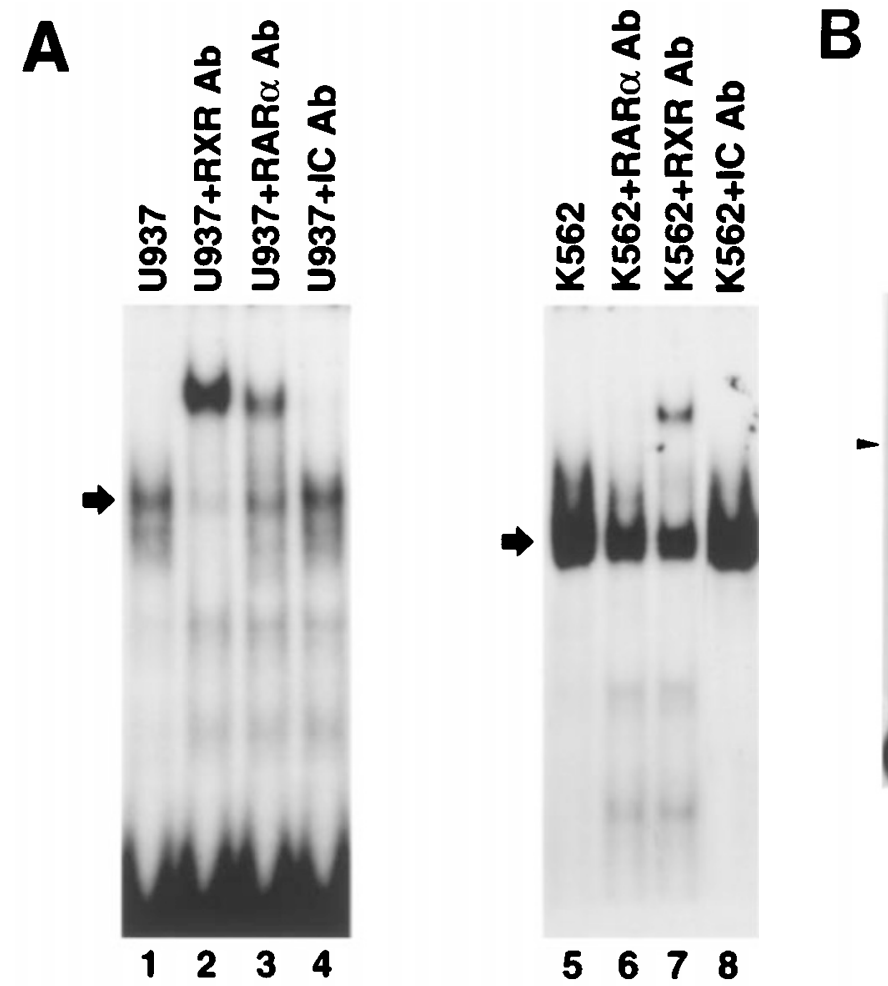

5678

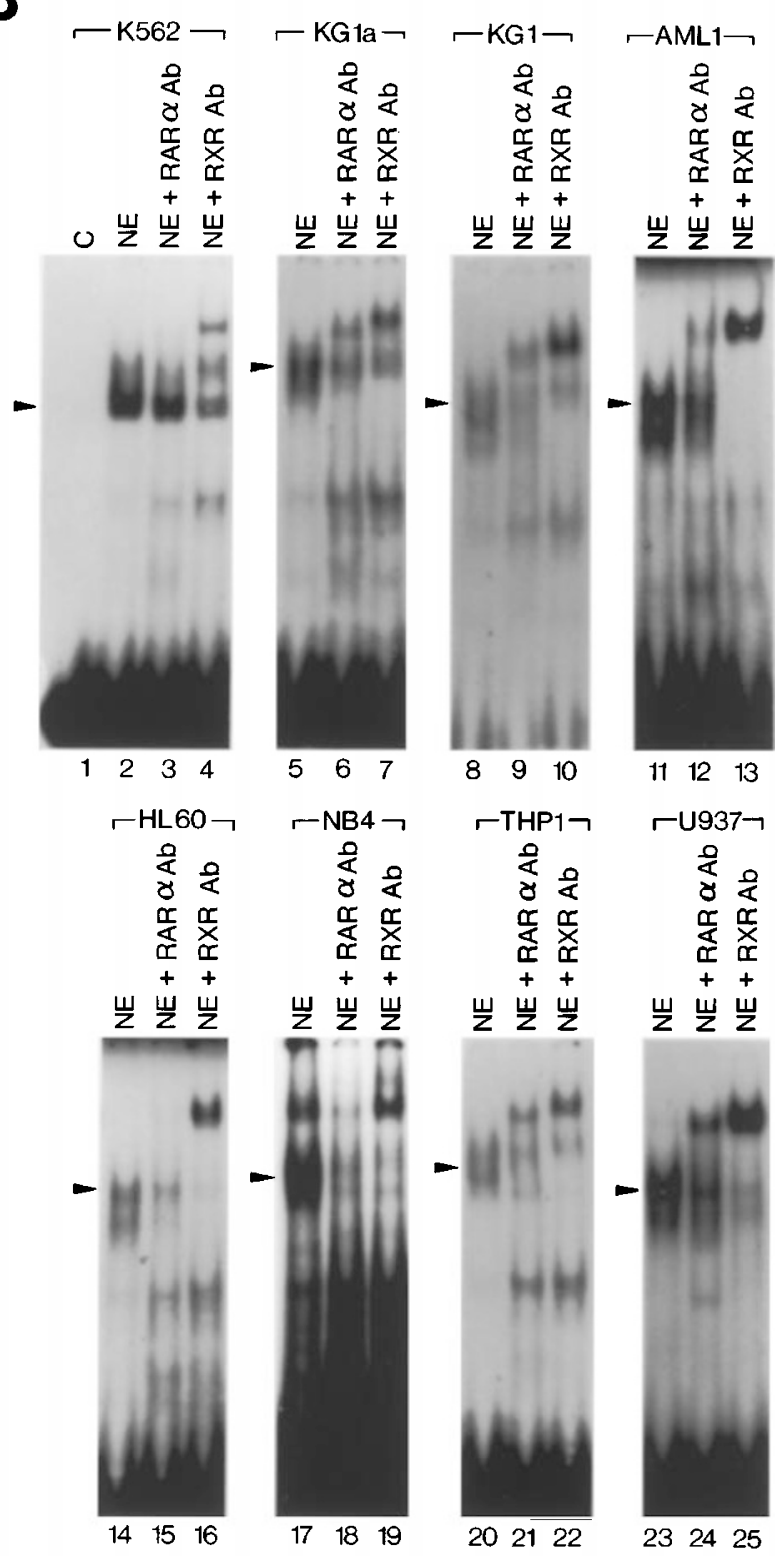

Figure 5 EMSA analysis performed by challenging nuclear extracts (NE) of the analyzed myeloid cell lines with a ${ }^{32} \mathrm{P}$-labeled RARE $\beta 2$ probe. The observed major shift complexes are indicated by arrows. The examined cell lines, and the added Ab, are reported at the top of each autoradiogram. To assess whether RAR $\alpha$ and RXR proteins participated to the formation of shift complexes, NE were respectively challenged with an anti-RAR $\alpha$ (RAR $\alpha$ Ab) or an anti-RXR $\alpha, \beta, \gamma(\mathrm{RXR} A b)$ antibody. (A) shows a control experiment, in which the effect of an isotype control (IC) Ab, on the band shift profile of U937 and K562 cells (lanes 4 and 8 , respectively), is compared to the EMSA pattern specifically promoted by addition of anti-RAR $\alpha$ (lanes 3 and 6 ) and anti-RXR Ab (lanes 2 and 7 ). (B) shows the EMSA results obtained in all the analyzed cell lines. In lane 1, the migration pattern of unincubated RARE $\beta 2$ oligomer $(C)$ is reported

observed in HL60, NB4, THP1 and U937 cells (Figure 8, middle panel, lanes 12-22), but not in the other cell lines (Figure 8, lower panel, lanes 1-11). GAPDH mRNA levels in the various analyzed RNA samples are superimposable (Figure 8, lower panel, lanes 1-22). Taken together these results show that expression of IRF1 and E3 genes is rapidly induced in the more mature M2/M3, M3 and M5 type cell lines, but not in the more undifferentiated cell contexts (myeloerythroid precursors and M0/M1 early myeloblasts). The isolated induction of the IRF-1 gene, without induction of E3 gene, observed in ATRA treated AML1 cells, is consistent with the activation of the apoptotic program, observed in these cells, since IRF-1 has also been proposed to be involved in apoptosis. $^{34}$

\section{Treatment of the analyzed cell lines with trichostatin A}

The discrepancy between the capacity of RAR $\alpha / R X R$ heterodimers to transactivate an exogenous RARE- $\beta 2$ 

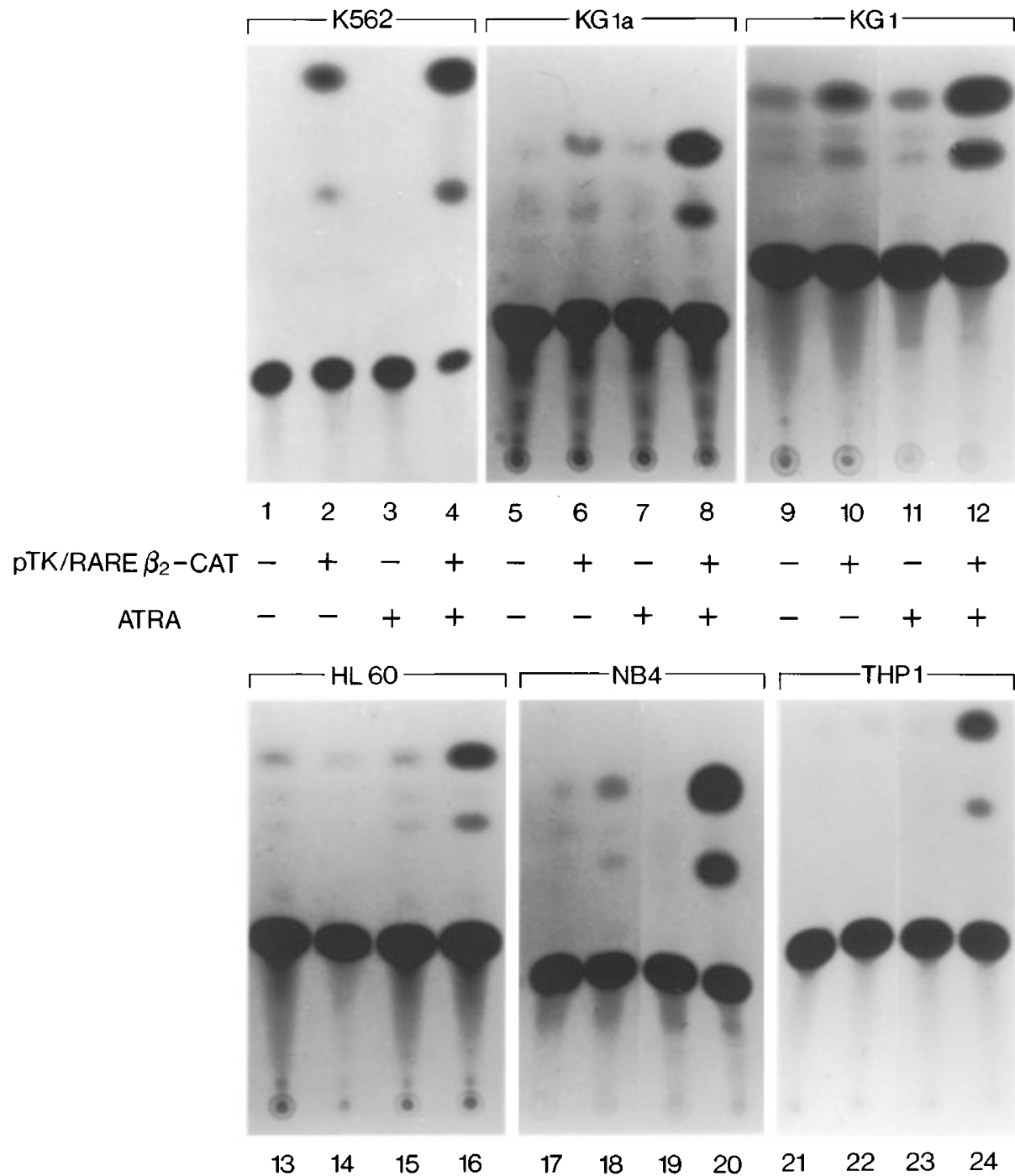

pTK/RARE $\beta_{2}-$ CAT


$-+-+$

ATRA

Figure 6 CAT assay performed on cell extracts of K562, KG1a, KG1, HL-60, NB4 and THP1 cell lines upon transfection with pTK/RARE $\beta 2-C A T$ expression vector. Each assay was performed electroporating cells without DNA (negative controls) in the absence (lanes 1, 5, 9, 13, 17 and 21) or presence (lanes $3,7,11$, 15,19 and 23) of $10^{-6}$ M ATRA, or with the used plasmids in absence (lanes 2, 6, 10,14, 18 and 22) or presence of $10^{-6}$ M ATRA (lanes 4, 8, 12, 16, 20 and 24). Normalization of the CAT assay was performed using different amounts of cell lysates based on the $\beta$-galactosidase activity of the co-transfected pMCV $\beta$ plasmid. A representative experiment is shown for each analyzed cell line

dependent promoter and the inability to activate the transcription of endogenous RA target genes, raises the possibility that the differentiation block observed in early leukemic ATRA non responsive myeloblasts, might reside in a chromatin mediated transcription repression. Histone deacetylation induced by histone deacetylase (HDAC) has been demonstrated to be an important mechanism of transcriptional regulation that leads to changes in chromatin conformation and to transcription repression. ${ }^{35}$ We therefore investigated if the HDAC inhibitor trichostatin A (TSA), was able to restore ATRA induced granulocytic differentiation of the more undifferentiated myeloid cell lines (K562, KG1a and KG1).
For this purpose cell lines were treated with $200 \mathrm{ng} / \mathrm{ml}$ TSA and $10^{-6} \mathrm{M}$ ATRA, separately or in association. Differentiation was then assessed by morphology (MGG staining), cytofluorimetric analysis (CD11b expression), NBT reduction assay and type II transglutaminase (TGase) mRNA expresion, as described. ${ }^{22,23}$

A 5 days treatment of $\mathrm{HL}-60$ and NB4 cells with ATRA/TSA, clearly enhanced the percentage of the more differentiated myeloid elements (metamyelocytes, band granulocytes and granulocytes), as compared to the same cells treated with ATRA alone $(40-55 \%$ versus $15-30 \%$ respectively) (not shown). Conversely none of the other 
analyzed cell lines (K562, KG1a, KG1, THP1, U937) assumed a granulocytic morphology after 5 days treatment with any of the tested compounds, and no additional effects were, to this regard, observed in the samples treated with ATRA/TSA association (data not shown).

Cytofluorimetric assessment of CD11b expression, in the various tested cell lines, did not show any synergistic effect

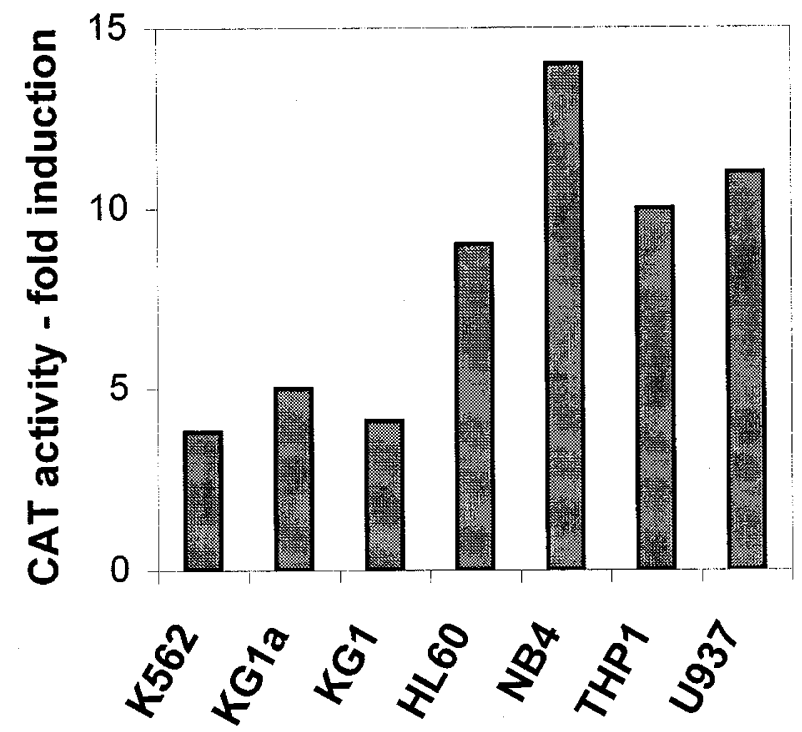

Figure 7 Densitometric analysis of ATRA induced CAT activity, obtained transfecting the analyzed myeloid cell lines with the pTK/RARE $\beta 2$-CAT expression vector. For each cell line the ratio between ATRA induced, and basal activity of the reporter construct has been shown (fold induction). Mean values obtained from three independent experiments have been reported having standard deviations lower than $20 \%$ between ATRA and TSA treatment (Figure 9), with the exception of only NB4 cells, where TSA enhanced ATRA induced expression of CD11b surface antigen.

Differentiation of HL-60 and NB4 cells with ATRA, resulted in a clear induction of NBT positivity (from 8 to $63 \%$ and from 0 to $34 \%$, respectively) (Figure 10). Furthermore TSA treatment of NB4 cells increased the differentiation effect obtained by ATRA alone (from 34 to $83 \%$ ) (Figure 10), as already described. ${ }^{23}$ What we observed in the more undifferentiated myeloid cell lines such as $\mathrm{K} 562$, KG1a and KG1 is that neither treatment with ATRA alone, nor stimulation with ATRA/TSA, was able to

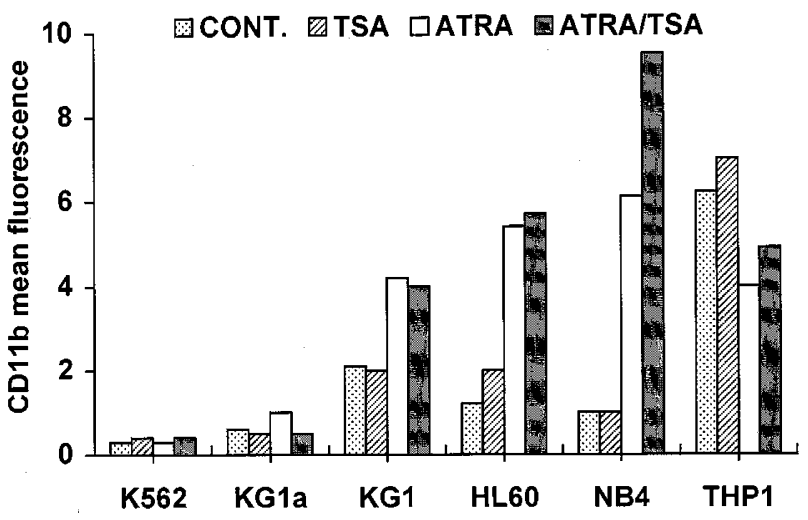

Figure 9 Cytofluorimetric analysis of CD11b surface antigen expression in untreated control (CONT) (dotted bars), TSA treated (gridded bars), ATRA treated (white bars) and ATRA/TSA treated (grey bars) cell lines. CD11b expression was estimated upon a $72 \mathrm{~h}$ treatment with the mentioned compounds. Representative mean fluorescence values, obtained from three independent experiments, have been reported in the shown histogram as arbitrary units. The variability among the performed experiments did not exceed $10 \%$ of the mean values

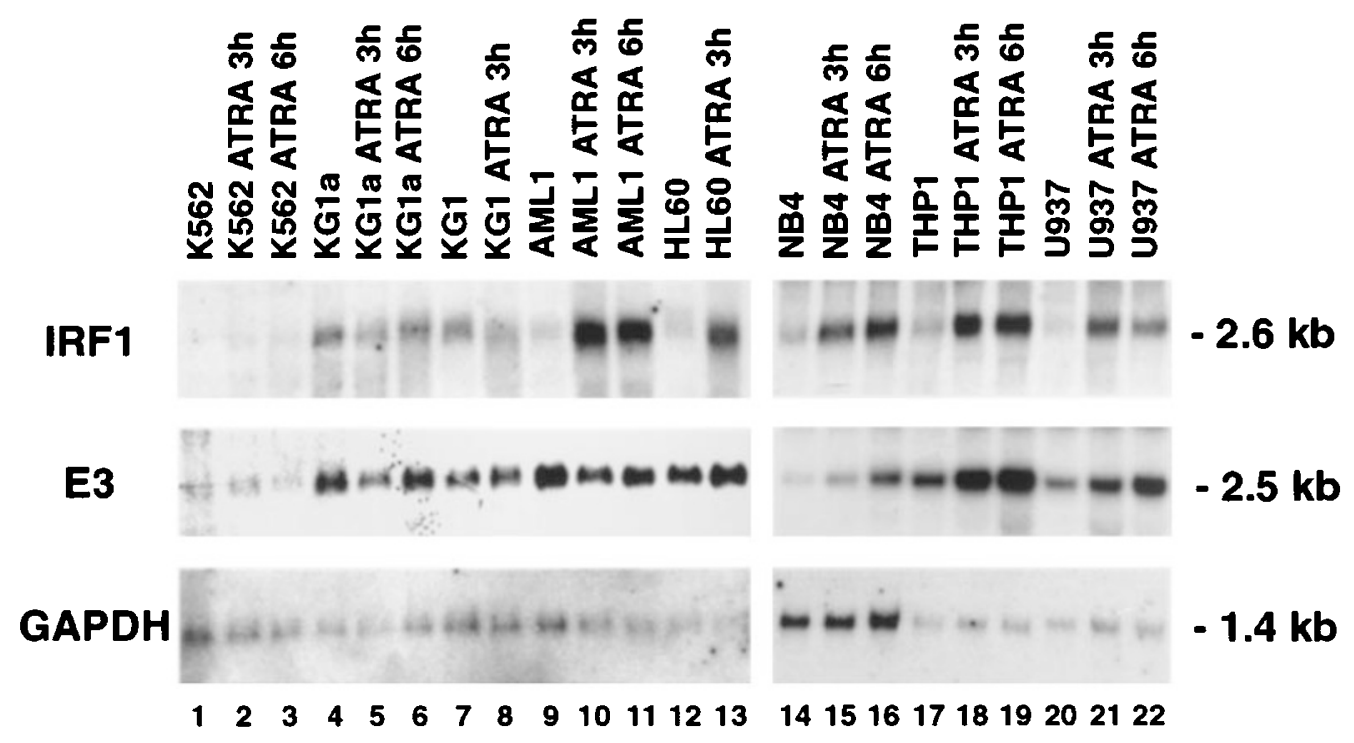

Figure 8 Northern blot analysis obtained hybridizing total RNAs of the studied myeloid cell lines, extracted before and after a 3-6h exposure to ATRA, with probes of RA target genes IRF-1 (upper panel) and E3 (middle panel). Hybridization with a probe of GAPDH (lower panel) was also performed to normalize the different RNA amounts. Analyzed cell lines together with the performed treatment are reported on the top of the figure. Sizes of detected mRNAs are instead reported on the right side of the figure 


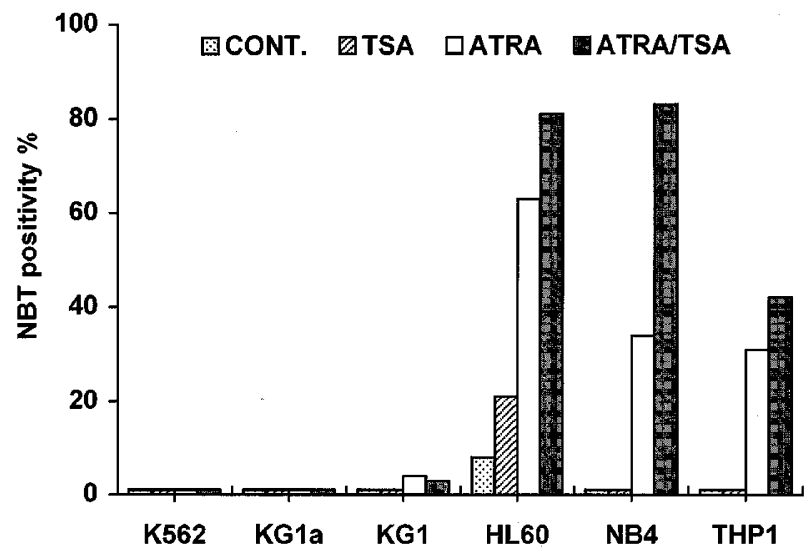

Figure 10 Histogram comparing the levels of NBT positivity, reported as percentage of positive cells, in untreated control (CONT) (dotted bars), TSA treated (gridded bars), ATRA treated (white bars) and ATRA/TSA treated (grey bars) cell lines. NBT reduction assay was performed after $72 \mathrm{~h}$ treatment with the used differentiation inducers. The reported values represent the mean of three independent experiments and standard deviations did not exceed $10 \%$ of the mean values

induce NBT activity (Figure 10), even after 5 days stimulation with the used compounds (data not shown). An increased NBT positivity was instead detected upon treatment with ATRA of the monoblastic THP1 cell line (from 0 to $31 \%$ ), which was not enhanced by TSA addition (Figure 10), and was coupled with a weak induction of CD14 antigen (about 40\% positive cells; not shown). These last results could be explained by the already described capacity of monoblastic cell lines to undergo monomacrophagic differentiation following treatment with ATRA alone $^{36,37}$ or ATRA/VD association. ${ }^{38-40}$

The expression of TGase, a RA target gene ${ }^{41,42}$ has been shown to be up-regulated following ATRA treatment of NB4 cells. ${ }^{43}$ Furthermore this transcriptional activation is enhanced by simultaneous exposure to TSA. ${ }^{22}$ To investigate if the combined treatment with ATRA and TSA was able, even partially, to activate the genetic program underlying granulocytic differentiation, we used the highly sensitive RT-PCR technique to analyze TGase mRNA expression in early myeloblastic, ATRA unresponsive cell lines. The obtained results indicate that TGase is highly expressed in K562 cells (Figure 11, upper panel, lane 1), but not in KG1a (Figure 11, upper panel, lane 5) and in KG1 (Figure 11, upper panel, lane 9) cells, where TGase mRNA is barely detectable. More importantly TGase mRNA levels are not significantly modified by exposure to TSA, ATRA or even ATRA/TSA of K562 (Figure 11, upper panel, lanes 2-4) and KG1a cells (Figure 11, upper panel, lanes $6-8)$. A very weak induction of TGase mRNA is detected in ATRA treated KG1 cells (Figure 11, upper panel, lane 11), while TSA has apparently no effect in these cells neither alone (Figure 11, upper panel, lane 10), nor associated with ATRA (Figure 11, upper panel, lane 12). As expected TGase is weakly expressed in ATRA responsive NB4 cells (Figure 11, upper panel, lane 13), and strongly induced by treatment with ATRA (Figure 11, upper panel, lane 15). TSA treatment does not induce TGase expression by itself

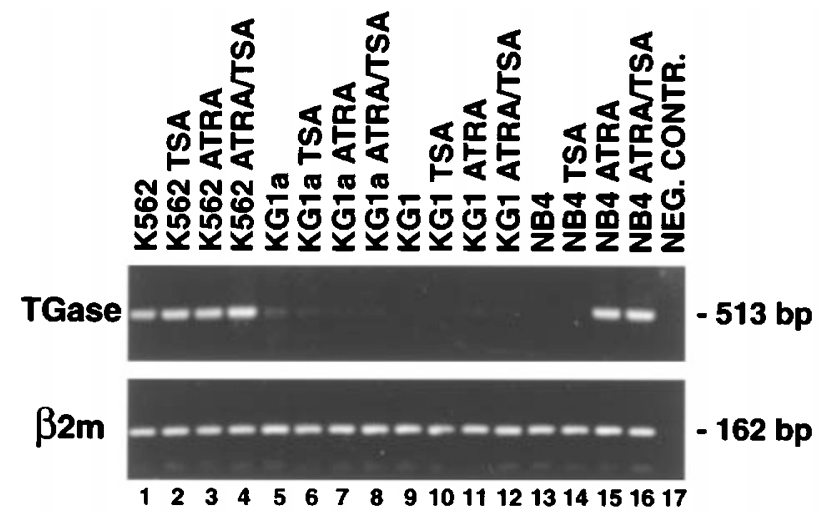

Figure 11 Messenger RNA expression of type II transglutaminase (TGase) (upper panel) and $\beta 2$-microglobulin $(\beta 2 \mathrm{~m})$ (lower panel) analyzed by the RTPCR technique in myeloid leukemic cell lines, before and after $48 \mathrm{~h}$ treatment with TSA, ATRA and ATRA/TSA. Agarose gels stained with ethidium bromide are shown. Cell lines and treatments are indicated at the top of the figure. In lane 17, the negative control, obtained performing RT-PCR amplification without cDNA template, is reported. The sizes of the amplified gene fragments are indicated on the right side of the picture

(Figure 11, upper panel, lane 14), and apparently does not enhance ATRA mediated expression of TGase in NB4 cells (Figure 11, upper panel, lane 16). This result is not surprising since the RT-PCR technique is not suitable to detect a twofold induction of gene expression, as that observed by other authors in ATRA/TSA treated NB4, ${ }^{22}$ assaying TGase enzyme activity.

\section{Discussion}

AMLs are heterogeneous neoplastic disorders characterized by the accumulation of a large number of leukemic blasts that fail to mature into functional, terminally differentiated, granulocytes or monocytes. ${ }^{2}$ The majority of AMLs carry cytogenetic abnormalities, that are supposed to contribute to the maturation arrest. ${ }^{5}$ These chromosomal aberrations are extremely heterogeneous ${ }^{3}$ and no tight association can be established between genetic abnormalities and the different AML phenotypes, the only exception being represented by APLs characterized by the PML-RAR $\alpha$ fusion gene. ${ }^{5}$ An efficacious therapeutic approach for AML is provided by the possibility to overcome the differentiation block of leukemic blast cells. ${ }^{9}$ APLs harboring the PML-RAR $\alpha$ fusion gene represent a clear evidence of successful differentiation therapy achieved with ATRA. ${ }^{17,18}$ Furthermore innovative therapeutic perspectives could be opened, in the future, by compounds which are able to modify chromatin conformation, like HDAC and DNA methyltransferase inhibitors. ${ }^{25}$ As mentioned above, AMLs having phenotypes distinct to M3AML, for example M0/M1 type or M5 type blast cells, are not responsive to ATRA induced granulocytic differentiation. ${ }^{26}$ To investigate the molecular mechanisms underlying such resistance to ATRA treatment we have analyzed RAR $\alpha$ expression and function in several myeloid leukemic cell lines, that are representative of various $F A B$ cytotypes, and more precisely: K562 (myelo-erythroid), KG1a and KG1 (M0/ 
M1), AML1 and HL60 (M2/M3), NB4 (M3), THP1 and U937 (M5). Among these cell lines only HL60 and NB4, i.e. M2-M3 and M3 type cells, resulted to be responsive to ATRA treatment. Cells having myelo-erythroid (K562), M0/M1 (KG1a, KG1) or M5 (THP1, U937) phenotypes are instead not responsive to ATRA induced granulocytic differentiation, as assessed by morphological and immunophenotypic analysis. Our results demonstrate that $\operatorname{RAR} \alpha$ protein is expressed, phosphorylated and able to heterodimerize with $\mathrm{RXR}$, in all the analyzed myeloid cell populations, regardless of their responsiveness to ATRA. Furthermore RAR $\alpha / R X R$ heterodimers are able to bind a RARE- $\beta 2$ element and to transactivate a RARE- $\beta 2$ dependent expression vector following interaction with ligand, in both ATRA responsive (M2/M3 and M3) and non responsive (M0/M1 and M5) cell contexts. On the other hand, the expression of endogenous $\mathrm{RA}$ target genes, as IRF1 and E3, is rapidly induced in the more differentiated analyzed cell lines, either ATRA responsive (M2/M3 and M3 type) or non responsive (M5 type), but not in the more undifferentiated ATRA unresponsive cell contexts (myelo-erythroid precursors and M0/M1 early myeloblasts). In these last cell lines treatment with ATRA also fails to induce the expression of TGase, another RA target gene. An interesting association emerges, from our data, between the transcriptional response induced by ATRA, and the presence of the lower size $54 \mathrm{kDa} R A R \alpha$ form, in the more differentiated M2/M3 and M5 type cells. These cells are in fact characterized by a clear induction of RA target genes and a high efficiency of ATRA dependent transactivation, suggesting that the lower size $54 \mathrm{kDa}$ RAR $\alpha$ form could be more efficient in terms of transcriptional activity, as compared to the higher size 57-58 $\mathrm{kDa} \operatorname{RAR} \alpha$ doublet. The absence of the $54 \mathrm{kDa}$ size RAR $\alpha$ protein in NB4 cells is not surprising, to this regard, since several evidences suggests that ATRA effects are mainly mediated by the PML-RAR $\alpha$ chimeric protein in this cells. ${ }^{44}$ The 57-58 and $54 \mathrm{kDa}$ RAR $\alpha$ forms still have a different size upon digestion of NE with AP (54 and $52 \mathrm{kDa}$ respectively), showing that phosphorylation is not entirely responsible for the observed pattern of RAR $\alpha$ expression. The expression of different RAR $\alpha$ isoforms could, in principle, account for these findings. Although seven distinct RAR $\alpha$ isoforms have been identified in the mouse, ${ }^{45}$ only the RAR $\alpha 1$ and RAR $\alpha 2$ isoforms have been, to date, characterized in human cells. RT-PCR experiments, performed using oligonucleotide primers able to detect the human RAR $\alpha 1$ and RAR $\alpha 2$ isoforms, ${ }^{31}$ showed that they are simultaneously expressed in all the examined cell lines (data not shown), as already demonstrated for normal bone marrow and APL cells. ${ }^{31}$ Other RAR $\alpha$ isoforms, distinct to RAR $\alpha 1$ and RAR $\alpha 2$, could however explain the presence of a differential pattern of $\mathrm{RAR} \alpha$ protein expression among the analyzed cell populations. It has to be pointed out that ATRA up-regulates the expression of RA target genes not only in M2-M3 type cells, but also in M5 type cells, as already reported by others, ${ }^{32,38}$ implying that this differentiation inducer is able to modulate the expression of RA responsive genes, regardless of its ability to promote granulocytic differentiation. This is not surprising, since THP1 and U937 cells, being already committed along the mono-macrophage maturation pathway, probably cannot undergo granulocytic differentiation. An intriguing observation is provided, to this regard, by the capacity of ATRA to trigger mono-macrophagic differentiation of M5 type cell lines, ${ }^{36,37}$ or to potentiate VD induced mono-macrophagic differentiation of the same cells. ${ }^{40,46}$ Besides promoting mono-macrophagic differentiation of leukemic monoblasts, ATRA also induces the monocytic differentiation of M2 type blast cells. ${ }^{47}$ The molecular mechanisms underlying the differentiation effect exerted by ATRA on M5 and M2 type blast cells, are poorly understood, but these findings may represent a further observation supporting the existence of an interplay between RA and VD intracellular pathways. ${ }^{38,46,47} \mathrm{~A}$ complete RA response pathway is not maintained in the more undifferentiated ATRA non responsive (myelo-erythroid and M0/M1) cell lines, where in spite of the presence of transcriptionally active RAR $\alpha /$ RXR heterodimers, ATRA is unable to induce the expression of endogenous RA target genes. The discrepancy between the capacity of $R A R \alpha / R X R$ heterodimers to transactivate an exogenous RARE- $\beta 2$ dependent vector and the inability to activate the transcription of endogenous RA target genes in M0/M1 type cells, rises the possibility that the differentiation block of these cells might reside in a chromatin mediated transcription repression. RAR $\alpha / R X R$ heterodimers, in their unliganded form, have been described to repress the transcription of RA target genes, by recruiting co-repressor complexes containing HDAC, that in turn induces a modification of chromatin which is not permissive for transcription. ${ }^{48}$ The ability of RAR $\alpha$ to behave as a transcriptional repressor is also supported by the recent observation that overexpression of a wild-type RAR $\alpha$ in primary hematopoietic stem cells, leads to a block of granulocytic differentiation. ${ }^{16}$ To assess the possible involvement of co-repressor complexes in maturation arrest of highly undifferentiated myeloid cell contexts, we investigated whether the HDAC inhibitor trichostatin A (TSA) was able to restore ATRA induced granulocytic differentiation of K562, KG1a and KG1 cell lines. Cell lines were then treated with TSA, ATRA or ATRA/TSA for 3-5 days, and then differentiation was estimated by immunophenotypic analysis, NBT reduction assay and morphology. A clear synergism between ATRA and TSA was observed after induction of granulocytic differentiation in ATRA responsive NB4 and HL60 cells, at least as assessed by morphology and NBT positivity. TSA treatment of NB4 cells also slightly enhanced ATRA induced expression of CD11b surface antigen. No ATRA/TSA synergism was detected when differentiation of HL-60 cells was evaluated by CD11b expression. This result is not surprising and it has already been reported by other authors, using comparable concentrations of the two compounds. ${ }^{48}$ Conversely in the other ATRA unresponsive cell lines, treatment with TSA is not able to re-activate ATRA induced granulocytic differentiation, showing that the differentiation block of early myeloblastic AMLs, besides being resistant to ATRA, is also TSA insensitive. TSA treatment of K562, KG1a and KG1 cells, in fact, was not only unable to restore a phenotypic response to ATRA, assessed by CD11b expression, NBT reduction and morphology, but it was also unable to activate the genetic program that leads to ATRA induced granulocytic differentiation, as shown by RT-PCR analysis of TGase mRNA expression. These findings are in agreement with the observation that TSA also fails to restore 
the differentiation capacity of M2 type blast cells carrying the $t(8 ; 21)$ translocation. ${ }^{24}$ Moreover they can be considered a further evidence supporting the hypothesis that histone acetylation facilitates transcription but is not sufficient to induce the transcription of an inactive gene. ${ }^{35}$

Taken together our data suggest that the control of granulocytic differentiation, in the early stages of leukemic myelopoiesis, might be regulated at the chromatin structure level by a mechanism that is apparently HDAC independent and might be represented, at least partly, by a reduced access of RAR $\alpha / R X R$ heterodimers to promoter regions of RA target genes. This hypothesis is also supported by the already reported observation that early leukemic myeloblasts express functional vitamin D3 receptors (VDR), but are unable to differentiate after treatment with VD. ${ }^{49}$ Apart from RAR $\alpha$, other transcription factors, such as PU.1, AML1 and $\mathrm{C} / \mathrm{EBP} \alpha$, are involved in the regulation of myeloid differentiation. ${ }^{4}$ Furthermore, several transcription regulatory elements, including the RAREs, have been shown to lie inside the promoter region of certain myeloid related genes, allowing to hypothesize that the expression of such genes is cooperatively activated by the interested transcription factors. Examples of this hypothetic cooperation are represented by $\mathrm{CD} 11 \mathrm{~b}$, myeloperoxidase and lactoferrin genes. ${ }^{50}$ Based on these considerations we cannot exclude that a functional impairment of myeloid transcription factors, distinct to $\operatorname{RAR} \alpha$, may also play a role in the resistance to ATRA induced differentiation of MO/M1 cells.

Further studies are necessary to clarify the molecular mechanisms underlying the maturation arrest of M0-M1 leukemic myeloblasts, in order to develop new differentiation strategies.

\section{Materials and Methods}

\section{Cell cultures}

The following hematopoietic cell lines were obtained from ATCC: K562 (myelo-erythroid precursors), KG1a (M0 type), KG1 (M1 type), AML1 and HL60 (M2-M3 type), NB4 (M3 type), THP1 (M5 type), U937 (histiocytic cells), and cultured in RPMI 1640 medium (GIBCO B.R.L., Life Technologies Inc., Gaithersburg, MD, USA), supplemented with $10 \%$ fetal calf serum (FCS) (GIBCO B.R.L.) and $2 \mathrm{mM} \mathrm{L-glutamine}$ (GIBCO B.R.L.). Differentiation was induced by treatment with $10^{-6} \mathrm{M}$ ATRA (Hoffman-La Roche, Basel, Switzerland) and monitored by May Grünwald Giemsa (MGG) staining, immunophenotypic analysis and NBT reduction assay, performed as described. ${ }^{12}$ When indicated, inhibition of HDAC activity was achieved by incubating cell cultures with TSA (Sigma, St. Louis, MO, USA) at concentrations ranging from $50-200 \mathrm{ng} / \mathrm{ml}$. The data presented in the Results section have been obtained with the higher concentration $(200 \mathrm{ng} / \mathrm{ml})$. With the only exception being U937 cells, that underwent a massive cell death following TSA treatment (at least at concentrations as high as $200 \mathrm{ng} /$ $\mathrm{ml}$ ), cell viability of the other cell samples, upon exposure to TSA, was generally high.

\section{Flow cytometry}

Cytofluorimetric analysis of surface antigen expression was performed as described. ${ }^{51}$ The following monoclonal antibodies (MoAb) were used for labeling cell samples: phycoerythrin-conjugated (PE) mouse anti-human CD11b (Becton Dickinson Immuno-cytochemistry Systems, San Jose, CA, USA), mouse anti-human CD14 PE (Becton Dickinson). Briefly each antibody was incubated at the proper dilution with cell samples in PBS containing $5 \%$ FCS for 30 min at $4{ }^{\circ} \mathrm{C}$. Cells were then washed twice, resuspended with PBS and analyzed by a Coulter Epics XL flow cytometer (Coulter Electronics Inc., Hialeah, FL, USA). Assessment of apoptosis was performed by flow cytometry as already described. ${ }^{52}$

\section{Nuclear extract preparation}

Nuclear extracts (NE) of the analyzed cell populations, before and after treatment with ATRA, were obtained as already described, ${ }^{53}$ with minor modifications. ${ }^{49}$ Protein concentration was evaluated by the Lowry method. De-phosphorylation was obtained by diluting NEs fourfold in gel shift buffer and incubating at $37^{\circ} \mathrm{C}$ for $30 \mathrm{~min}$ in the presence of calf intestine alkaline phosphatase (AP) (Promega, Madison, WI, USA). ${ }^{29}$ As control, nuclear extracts were also incubated in the same experimental conditions without AP to exclude a nonspecific degradation of the nuclear receptor.

\section{Western blotting}

Expression of RAR $\alpha$ protein in NE of the studied cell lines was performed by Western blot analysis as described ${ }^{54}$ with some modifications. ${ }^{49}$ Briefly: $50 \mu \mathrm{g}$ of NE of each sample were dissolved in $1 \times$ reducing loading buffer $(50 \mathrm{mM}$ Tris $\mathrm{pH} 8,5 \% \quad \beta$ mercaptoethanol, $2 \%$ SDS, $0.1 \%$ Bromophenol Blue, $10 \%$ glycerol), loaded onto $7.5-10 \%$ SDS-PAGE and electrophoresed in TGS buffer (25 mM Tris pH 8.3, $250 \mathrm{mM}$ glycine, $0.1 \%$ SDS). The separated proteins were transferred at $4^{\circ} \mathrm{C}$ onto a nitrocellulose sheet by electroblotting procedure in TGM buffer ( $25 \mathrm{mM}$ Tris $\mathrm{pH} 8.3$, $250 \mathrm{mM}$ glycine, $20 \%$ methanol) for $2 \mathrm{~h}$ at $1 \mathrm{~A}$. In order to monitor the electroblotting efficiency the membrane was stained in $0.2 \%$ Ponceau $\mathrm{S} / 0.3 \% \mathrm{TCA}$ and destained in $0.3 \% \mathrm{TCA}$. Membranes were preblocked in blocking solution (10 mM Tris $\mathrm{pH} 8,150 \mathrm{mM} \mathrm{NaCl}, 0.05 \%$ Tween 20, TBST, supplemented with $4 \mathrm{mg} / \mathrm{ml}$ normal serum) for $1 \mathrm{~h}$ at room temperature (rt), incubated for $1 \mathrm{~h}$ at rt with a 1:500 dilution of the RP $\alpha$ $(F)$ rabbit policlonal anti-RAR $\alpha$ primary antibody (kindly provided by $\mathrm{Dr}$. $P$ Chambon) and then with the indicated secondary antibody HRP. conjugated $(1: 5000)$ ( $1 \mathrm{~h} \mathrm{at} \mathrm{rt})$ in blocking solution. The detection was carried out by ECL method.

\section{Gel shift assay}

All the oligonucleotides were synthesized with an automated solid phase DNA sinthesizer (Applied Biosystem, Inc., Foster City, CA, USA; Mod. 394 A) with the standard phosphoramidite chemistry, purified by several extractions with $\mathrm{NH}_{4} \mathrm{OH}$, incubated at $56^{\circ} \mathrm{C}$ for $16 \mathrm{~h}$, and ethanol precipitated or purified by PAGE. The following single stranded oligomers, already reported by other authors ${ }^{55}$ and their complement were synthesized to be used as probes in the gel shift assay: 5'-TCGACGGGTAGGGTTCACCGAAAGTTCACTCGC, RARE- $\beta 2 ; 5$ '-AGCTTCAGGTCACCAGGAGGTCAGAGAGC, DR5. These oligonucleotides were purified by PAGE following by electroelution, and annealed in equimolar amounts, as previously described. ${ }^{56}$ The double stranded oligodeoxynucleotides, again purified by PAGE and electroelution, were end labeled (100 ng) adding to $5 \times$ kinase buffer $\left(0.25 \mathrm{M}\right.$ Tris- $\mathrm{HCl}, \mathrm{pH} 7.5,0.1 \mathrm{M} \mathrm{MgCl}_{2}$, $50 \mathrm{mM}$ dithiothreitol, $1 \mathrm{mM}$ spermidine, and $1 \mathrm{mM}$ EDTA), [ $\left.\gamma^{32} \mathrm{P}\right]$ ATP (50 $\mu \mathrm{Ci}$; specific activity $3000 \mathrm{Ci} / \mathrm{mmol}$ ) and $10 \mathrm{U}$ of T4 polynucleotide 
kinase (Promega, Madison, WI, USA), to a final volume of $20 \mu \mathrm{l}$. The mixture was incubated at $37^{\circ} \mathrm{C}$ for $1 \mathrm{~h}$ followed by extraction with 1 volume of $1: 1$ phenol/chloroform and ethanol precipitation. Specific radioactivities ranged from $1-3 \times 10^{8}$ c.p.m. $/ \mu \mathrm{g}$ DNA. Electrophoretic mobility shift assay (EMSA) was performed as described. ${ }^{49}$ Briefly, NE (15 $\mu \mathrm{g}$ protein) were incubated with $5 \mu \mathrm{g}$ poly (I:C) (Pharmacia, Piscataway, NJ, USA), for $20 \mathrm{~min}$ at room temperature in $1 \times \mathrm{ge}$ shift buffer (10 mM Tris- $\mathrm{HCl} \mathrm{pH} 7.5,50 \mathrm{mM} \mathrm{KCl}, 5 \mathrm{mM} \mathrm{MgCl}_{2}, 1 \mathrm{mM}$ DTT, $1 \mathrm{mM}$ EDTA and $15 \%$ glycerol). The labeled oligonucleotide was then added $(1 \mathrm{ng}$ ) prolonging the incubation for $30 \mathrm{~min}$ (final volume $20 \mu \mathrm{l})$. When indicated, specific antibodies were added to the incubation mixture $10 \mathrm{~min}$ before the addition of the probe. Specificity of the shift complexes was also confirmed by adding 100 -fold excess cold RARE- $\beta 2$ or DR5 oligonucleotides or an isotype control antibody (mouse IgG) (Becton Dickinson). The following antibodies were used: Ab9 $\alpha$ (F) (mouse monoclonal anti-RAR $\alpha$, kindly provided by Dr. P Chambon); RX-1D12 (mouse monoclonal anti-RXR $\alpha,-\beta,-\gamma$, kindly provided by Dr. $P$ Chambon). All the antibodies were added to the samples 1:20. The reaction mixtures were then electrophoresed on a $5 \%$ polyacrylamide gel in $0.5 \times$ TBE $(45 \mathrm{mM}$ Tris base, $45 \mathrm{mM}$ boric acid, $4 \mathrm{mM}$ EDTA), pre-run for $1 \mathrm{~h}$ at room temperature. Finally the gel was fixed, dried in a vacuum essicator, and exposed to X-ray films (2$4 \mathrm{~h})$.

\section{RNA analysis}

Total cellular RNA was extracted using a modification of the guanidinium-cesium chloride centrifugation technique. ${ }^{57}$ For Northern blot analysis RNA samples were electrophoresed on $1 \%$ agaroseformaldehyde, blotted to nylon membranes and then hybridized with full length cDNA probes of IRF1 $1{ }^{32} \mathrm{E}^{33}$ and GAPDH gene, ${ }^{58}$ after $\left[{ }^{32} \mathrm{P}\right]$ multiprime labeling. The synthesized oligomers used as primers in the RT - PCR analysis were previously compared with the NIH gene bank by DNAsis software (Hitachi, Brisbaine, CA, USA) in order to avoid homologies with other gene sequences. For all the analyzed genes, oligonucleotides primers were designed on distinct exons, in order to exclude a possible genomic DNA contamination of the RNA samples. Messenger RNA expression of type II transglutaminase (TGase) gene was analyzed by RT-PCR, performed as previously reported, ${ }^{59}$ using the following oligonucleotide primers: TGase direct primer (DP), 5' -AATCTCA-CGGAGGGTCTCGGC-3'; TGase reverse primer (RP), 5'-CCGAGTCCAG-GTACACAGCATCC-3'. Normalization of amplified RNAs was carried out by means of the $\beta 2$ microglobulin $(\beta 2 \mathrm{~m})$ 'housekeeping' gene, performing a RT-PCR reaction in which the following oligonucleotide primers were used: $\beta 2 \mathrm{~m}$ DP, 5'-CTCGCGCTACTCTC-TCTTTC-T-3'; $\beta 2 \mathrm{~m}$ RP, 5'-TCCATTCTTCAGTAAGTCAACT-3'. Distinct direct primers were used for RT -PCR analysis of RAR $\alpha 1$ and RAR $\alpha 2$ isoforms (RAR $\alpha 1$ DP and RAR $\alpha 2$ DP, respectively), in combination with a common reverse primer (RAR $\alpha 1-2$ $\mathrm{RP})$, as already reported by others. ${ }^{31}$ These oligonucleotide primers were as follows: RAR $\alpha 1$ DP 5'-GCCAGGCGCTCTGACCACTC-3'; RAR $\alpha 2$ DP 5'-CCACCCCTAATCCCTTCCTA-3'; RAR $\alpha 1-2$ RP 5'AGCCCTTGCAGCCCTCACAG-3'.

\section{Cell transfection}

The following plasmids were used in the transfection experiments: (1) $\operatorname{pCMV} \beta$ (Clontech Laboratories Inc., Palo Alto, CA, USA), a $\beta$ galactosidase ( $\beta$-gal) expression vector; (2) pTK/RARE $\beta 2$-CAT (kindly provided by $\mathrm{V}$ Colantuoni), containing the chloramphenicol acetyltransferase (CAT) reporter gene under the control of the RARE $\beta 2$ enhancer and the minimal promoter region of the human TK gene $(-104 /+51) .2 .5 \times 10^{7}$ cells were transfected by electroporation with
$30 \mu \mathrm{g}$ of $\mathrm{pTK} / \mathrm{RARE} \beta 2-\mathrm{CAT}$ and $5 \mu \mathrm{g}$ of $\mathrm{pCMV} \beta$ plasmid. Electroporation was performed at $250 \mathrm{~V}$ and $960 \mu \mathrm{F}$ (Gene Pulser Apparatus, BioRad, Hercules, CA, USA). Transfected cells were cultured for $48 \mathrm{~h}$ in RPMI 1640 medium containing $15 \%$ FCS, with or without $10^{-6} \mathrm{M}$ ATRA and then harvested for CAT assays, performed using radiolabeled chloramphenicol. ${ }^{49} \beta$-gal activity was used to normalize the amount of cell extract to be assayed for CAT activity.

\section{Acknowledgements}

This work has been supported by a grant from A.I.R.C.

\section{References}

1. Bonnet $D$ and Dick JE (1997) Human acute myeloid leukemia is organized as a hierarchy that originates from a primitive hematopoietic cell. Nat. Med. 3: 730 737

2. Ferrari S, Manfredini R, Grande A, Torelli G and Torelli U (1992) Proliferation, differentiation arrest, and survival in leukemic blastcells. Ann. NY Acad. Sci. 663: $202-214$

3. Zeleznikle NJ, Nucifora G and Rowley JD (1995) The molecular biology of myeloproliferative disorders as revealed by chromosomal abnormalities [review]. Semin. Hematol. 32: 201-219

4. Tenen DG, Hromas R, Licht JD and Zhang DE (1997) Transcription factors, normal myeloid development, and leukemia. Blood 90: 489-519

5. Look AT (1997) Oncogenic transcription factors in the human acute leukemias. Science 278: 1059-1064

6. Bennett JM, Catovsky D, Daniel MT, Flandrin G, Galton DA, Gralnick HR and Sultan C (1976) Proposals for the classification of the acute leukemias. FrenchAmerican-British (FAB) co-operative group. Br. J. Haematol. 33: 451-458

7. Drexler HG (1987) Classification of acute myeloid leukemias - a comparison of FAB and immunophenotyping. Leukemia 1: 697-705

8. Francis R and Balkwill FR (1989) Colony stimulating factors and myeloid leukemia. In Cytokines in cancer, (Oxford University Press) pp. 132-138

9. Olsson I, Bergh G, Ehinger M and Gullberg U (1996) Cell differentiation in acute myeloid leukemia. Eur. J. Haematol. 57: 1-16

10. Lea MA (1992) Action of exogenous differentiating agents on gene expression in cancer cells. Crit. Rev. Oncol. Hematol. 13: 189-214

11. Purton LE, Bernstein ID and Collins SJ (1999) All-trans retinoic acid delays the differentiation of primitive hematopoietic precursors (lin-c-kit+Sca-1(+)) while enhancing the terminal maturation of committed Granulocyte/Monocyte progenitors [In Process Citation]. Blood 94: 483-495

12. Breitman TR, Selonick SE and Collins SJ (1980) Induction of differentiation of the human promyelocytic leukemia cell line (HL-60) by retinoic acid. Proc. Natl. Acad. Sci. USA 77: 2936-2940

13. Collins SJ, Robertson KA and Mueller L (1990) Retinoic acid-induced granulocytic differentiation of $\mathrm{HL}-60$ myeloid leukemia cells is mediated directly through the retinoic acid receptor (RAR-alpha). Mol. Cell. Biol. 10: 2154-2163

14. Tsai S and Collins SJ (1993) A dominant negative retinoic acid blocks neutrophil differentiation at the promyelocyte stage. Proc. Natl. Acad. Sci. USA 90: 7153 7157

15. Tsai S, Bartelmez S, Heyman R, Damm K, Evans R and Collins SJ (1992) A mutated retinoic acid receptor-alpha exhibiting dominant-negative activity alters the lineage development of a multipotent hematopoietic cell line. Genes Dev. 6 : 2258-2269

16. Du C, Redner RL, Cooke MP and Lavau C (1999) Overexpression of wild-type retinoic acid receptor alpha (RARalpha) recapitulates retinoic acid-sensitive transformation of primary myeloid progenitors by acute promyelocytic leukemia RARalpha-fusion genes. Blood 94: 793-802

17. Castaigne S, Chomienne C, Daniel MT, Ballerini P, Berger R, Fenaux P and Degos L (1990) All-trans retinoic acid as a differentiation therapy for acute promyelocytic leukemia. I. Clinical results [see comments]. Blood 76: $1704-$ 1709

18. Warrell RPJ, Frankel SR, Miller Jr WH, Scheinberg DA, Itri LM, Hittelman WN, Vyas R, Andreeff M, Tafuri A, Jakubowski A, Gabrilove S, Gordon MS and Dmitrovsky E (1991) Differentiation therapy of acute promyelocytic leukemia with tretinoin (all-trans-retinoic acid). N. Engl. J. Med. 324: 1385-1393 
19. Kakizuka A, Miller Jr WH, Umesono K, Warrell Jr RP, Frankel SR, Murty VV, Dmitrovsky E and Evans RM (1991) Chromosomal translocation t(15;17) in human acute promyelocytic leukemia fuses rar alpha with a novel putative transcription factor, pml. Cell 66: 663-674

20. de-The H, Chomienne C, Lanotte M, Degos L and Dejean A (1990) The t(15;17) translocation of acute promyelocytic leukemia fuses the retinoic acid receptor alpha gene to a novel transcribed locus. Nature 347: 558-561

21. Alcalay M, Zangrilli D, Pandolfi PP, Longo L, Mencarelli A, Giacomucci A, Rocchi M, Biondi A, Rambaldi A, Lo CF, Diverio D, Grignani F and Pelicci PG (1991) Translocation breakpoint of acute promyelocytic leukemia lies within the retinoic acid receptor alpha locus. Proc. Natl. Acad. Sci. USA 88: $1977-$ 1981

22. Grignani F, De-Matteis S, Nervi C, Tomassoni L, Gelmetti V, Cioce M, Fanelli M, Ruthardt M, Ferrara FF, Zamir I, Seiser C, Lazar MA, Minucci S and Pelicci PG (1998) Fusion proteins of the retinoic acid receptor-alpha recruit histone deacetylase in promyelocytic leukemia. Nature 391: 815-818

23. Lin RJ, Nagy L, Inoue S, Shao W, Miller Jr WH and Evans RM (1998) Role of the histone deacetylase complex in acute promyelocytic leukemia. Nature 391: 811-814

24. Gelmetti V, Zhang J, Fanelli M, Minucci S, Pelicci PG and Lazar MA (1998) Aberrant recruitment of the nuclear receptor corepressor-histone deacetylase complex by the acute myeloid leukemia fusion partner ETO. Mol. Cell. Biol. 18: $7185-7191$

25. Redner RL, Wang J and Liu JM (1999) Chromatin remodeling and leukemia: new therapeutic paradigms. Blood 94: 417-428

26. Miller CW and Koeffler HP (1990) In vivo and in vitro differentiation of myeloid leukemic cells. In The biology of human leukemia, Mauer AM, ed (Baltimore and London: The John Hopkins University Press) pp. 152-176

27. Lubbert M, Herrmann F and Koeffler HP (1991) Expression and regulation of myeloid-specific genes in normal and leukemic myeloid cells. Blood 77: 909924

28. Nagamura F, Nagamura IT, Tojo A, Minamihisamatsu M, Tanabe T,Zaike Y, Tani $\mathrm{K}$, Saisho $\mathrm{H}$ and Asano S (1998) Establishment of novel cell lines derived from two patients with chronic myelogenous leukemia in blast crisis; IMS-BC1 and IMS-BC2 which exhibit markedly different sensitivity to apoptosis. Int. J. Hematol. 67: 283-294

29. Lefebvre P, Gaub MP, Tahayato A, Rochette Egly C and Formstecher P (1995) Protein phosphatases 1 and $2 A$ regulate the transcriptional and DNA binding activities of retinoic acid receptors. J. Biol. Chem. 270: 10806-10816

30. Zhu J, Gianni M, Kopf E, Honore N, Chelbi AM, Koken M, Quignon F, Rochette EC and de-The $\mathrm{H}$ (1999) Retinoic acid induces proteasome-dependent degradation of retinoic acid receptor alpha (RARalpha) and oncogenic RARalpha fusion proteins. Proc. Natl. Acad. Sci. USA 96: 14807-14812

31. Li YP, Andersen J, Zelent A, Rao S, Paietta E, Tallman MS, Wiernik PH and Gallagher RE (1997) RAR alpha1/RAR alpha 2-PML mRNA expression in acute promyelocytic leukemia cells: a molecular and laboratory-clinical correlative study. Blood 90: 306-312

32. Matikainen S, Ronni T, Hurme M, Pine R and Julkunen I (1996) Retinoic acid activates interferon regulatory factor- 1 gene expression in myeloid cells. Blood 88: $114-123$

33. Scott LM, Mueller L and Collins SJ (1996) E3, a hematopoietic-specific transcript directly regulated by the retinoic acid receptor alpha. Blood 88: 2517-2530

34. Lallemand C, Bayat SM, Blanchard B and Tovey MG (1997) Identification of a novel transcriptional regulatory element common to the p53 and interferon regulatory factor 1 genes. J. Biol. Chem. 272: 29801-29809

35. Pazin MJ and Kadonaga JT (1997) What's up and down with histone deacetylation and transcription? Cell 89: $325-328$

36. Matikainen S and Hurme M (1994) Comparison of retinoic acid and phorbol myristate acetate as inducers of monocytic differentiation. Int. J. Cancer 57: 98 103

37. Olsson IL and Breitman TR (1982) Induction of differentiation of the human histiocytic lymphoma cell line U-937 by retinoic acid and cyclic adenosine $3^{\prime}: 5^{\prime}$ monophosphate-inducing agents. Cancer Res. 42: 3924-3927

38. Botling J, Oberg F, Torma H, Tuohimaa P, Blauer M and Nilsson K (1996) Vitamin D3-and retinoic acid-induced monocytic differentiation: interactions between the endogenous vitamin D3 receptor, retinoic acid receptors, and retinoid $X$ receptors in U-937 cells. Cell Growth Differ. 7: 1239-1249
39. Masciulli R, Testa U, Barberi T, Samoggia P, Tritarelli E, Pustorino R, Mastroberardino G, Camagna A and Peschle C (1995) Combined vitamin D3/ retinoic acid induction of human promyelocytic cell lines: enhanced phagocytic cell maturation and hybrid granulomonocytic phenotype. Cell Growth Differ. 6 : 493-503

40. Defacque H, Commes T, Sevilla C, Rochette EC and Marti J (1994) Synergistic differentiation of U937 cells by all-trans retinoic acid and 1 alpha, 25dihydroxyvitamin D3 is associated with the expression of retinoid $\mathrm{X}$ receptor alpha. Biochem. Biophys. Res. Commun. 203: 272-280

41. Nagy L, Saydak M, Shipley N, Lu S, Basilion JP, Yan ZH, Syka P, Chandraratna RA, Stein JP, Heyman RA and Davies PJ (1996) Identification and characterization of a versatile retinoid response element (retinoic acid receptor response element-retinoid $\mathrm{X}$ receptor response element) in the mouse tissue transglutaminase gene promoter. J. Biol. Chem. 271: 4355-4365

42. Yan ZH, Noonan S, Nagy L, Davies PJ and Stein JP (1996) Retinoic acid induction of the tissue transglutaminase promoter is mediated by a novel response element. Mol. Cell. Endocrinol. 120: 203-212

43. Benedetti L, Grignani F, Scicchitano BM, Jetten AM, Diverio D, Lo CF, Avvisati G, Gambacorti PC, Adamo S, Levin AA, Pelicci PG and Nervi C (1996) Retinoidinduced differentiation of acute promyelocytic leukemia involves PMLRARalpha-mediated increase of type Il transglutaminase. Blood 87: 1939-1950

44. Melnick A and Licht JD (1999) Deconstructing a disease: RARalpha, its fusion partners, and their roles in the pathogenesis of acute promyelocytic leukemia. Blood 93: 3167-3215

45. Leroy P, Krust A, Zelent A, Mendelsohn C, Garnier JM, Kastner P, Dierich A and Chambon $P$ (1991) Multiple isoforms of the mouse retinoic acid receptor alpha are generated by alternative splicing and differential induction by retinoic acid. EMBO J. 10: $59-69$

46. Nakajima H, Kizaki M, Ueno H, Muto A, Takayama N, Matsushita H, Sonoda A and Ikeda $Y$ (1996) All-trans and 9-cis retinoic acid enhance 1,25dihydroxyvitamin D3-induced monocytic differentiation of U937 cells. Leuk. Res. 20: 665-676

47. Manfredini R, Trevisian F, Grande A, Tagliafico E, Montanari M, Lemoli R, Visani $G$, Tura S and Ferrari S (1999) Induction of a functional vitamin D receptor in alltrans-retinoic acid-induced monocytic differentiation of M2-type leukemic blast cells. Cancer Res. 59: 3803-3811

48. Nagy L, Kao HY, Chakravarti D, Lin RJ, Hassig CA, Ayer DE, Schreiber SL and Evans RM (1997) Nuclear receptor repression mediated by a complex containing SMRT, mSin3A, and histone deacetylase. Cell 89: 373-380

49. Grande A, Manfredini R, Pizzanelli M, Tagliafico E, Balestri R, Trevisan F, Barbieri D, Franceschi C, Battini R and Ferrari S (1997) Presence of a functiona vitamin $D$ receptor does not correlate with vitamin D3 phenotypic effects in myeloid differentiation. Cell Death Differ. 4: 497-505

50. Lawson ND and Berliner N (1999) Neutrophil maturation and the role of retinoic acid. Exp. Hematol. 27: 1355-1367

51. Grande A, Piovani B, Aiuti A, Ottolenghi S, Mavilio F and Ferrari G (1999) Transcriptional targeting of retroviral vectors to the erythroblastic progeny of transduced hematopoietic stem cells. Blood 93: $3276-3285$

52. Manfredini R, Grande A, Tagliafico E, Barbieri D, Zucchini P, Citro G, Zupi G, Franceschi C, Torelli $U$ and Ferrari S (1993) Inhibition of c-fes expression by an antisense oligomer causes apoptosis of HL60 cells induced to granulocytic differentiation. J. Exp. Med. 178: 381-389

53. Dignam JD, Lebovitz RM and Roeder RG (1983) Accurate transcription initiation by RNA polymerase II in a soluble extract from isolated mammalian nuclei. Nucleic Acids Res. 11: 1475-1489

54. Burnette WN (1981) 'Western blotting': electrophoretic transfer of proteins from sodium dodecyl sulfate-polyacrylamide gels to unmodified nitrocellulose and radiographic detection with antibody and radioiodinated protein $A$. Anal. Biochem. 112: 195-203

55. Umesono K, Murakami KK, Thompson CC and Evans RM (1991) Direct repeats as selective response elements for the thyroid hormone, retinoic acid, and vitamin D3 receptors. Cell 65: $1255-1266$

56. Ferrari S, Battini R and Molinari S (1994) Specific binding to vitamin D response elements of chicken intestinal DNA-binding activity is not related to the vitamin D receptor. Mol. Endocrinol. 8: 173-181

57. MacDonald RJ, Swift GH, Przybyla AE and Chirgwin JM (1987) Isolation of RNA using guanidinium salts. Methods Enzymol. 152: 219-227 
58. Tso JY, Sun XH, Kao TH, Reece KS and Wu R (1985) Isolation and characterization of rat and human glyceraldehyde-3-phosphate dehydrogenase cDNAs: genomic complexity and molecular evolution of the gene. Nucleic Acids Res. 13: 2485-2502
59. Grande A, Manfredini R, Tagliafico E, Balestri R, Pizzanelli M, Papa S, Zucchini P, Bonsi L, Bagnara G, Torelli U and Ferrari S (1995) All trans retinoic acid induces simultaneously granulocytic differentiation and expression of inflammatory cytokines in HL 60 cells. Exp. Hematol. 23: 117-125 